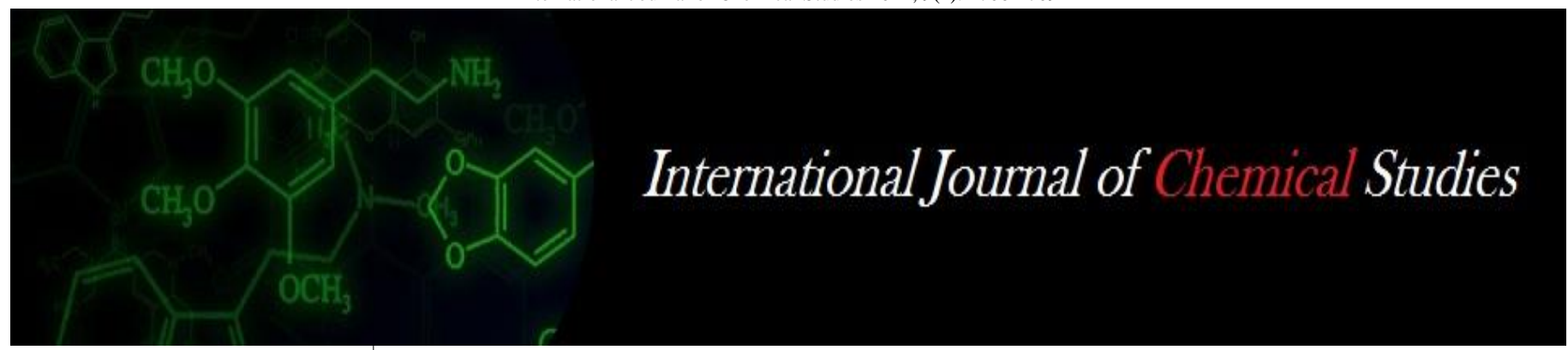

P-ISSN: 2349-8528

E-ISSN: 2321-4902

www.chemijournal.com

IJCS 2021; 9(1): 2706-2709

(C) 2021 IJCS

Received: 04-11-2020

Accepted: 16-12-2020

Sneha Kshirsagar

Ph.D., Scholar, Department of

Vegetable Science, Faculty of

Horticulture, Dr. P.D.K.V.

Akola, Maharashtra, India

PK Nagre

Dean, Department of Vegetable

Science, Faculty of Horticulture,

Dr. P.D.K.V., Akola,

Maharashtra, India

\section{Effect of fertigation levels and intervals on growth performance of Bittergourd}

\section{Sneha Kshirsagar and PK Nagre}

DOI: https://doi.org/10.22271/chemi.2021.v9.i1al.11635

\begin{abstract}
A field experiment was conducted during kharif 2018-2019 and summer 2019-2020 to standardize the fertigation levels and intervals for assessing growth performance viz., vine length $(\mathrm{cm})$, number of branches, leaf area $\left(\mathrm{cm}^{2}\right)$ and chlorophyll content $(\mathrm{mg} / \mathrm{g})$ of bittergourd. The experiment was laid out in Split Plot Design with two replications. The main plot treatment consist of five fertigation levels (F) viz., $\mathrm{F}_{1}-100 \%$ of RDF through soil as a straight fertilizer, $\mathrm{F}_{2}-120 \%$ of RDF through water soluble fertilizer, $\mathrm{F}_{3}-100 \%$ of RDF through water soluble fertilizer, $\mathrm{F}_{4}-80 \%$ of RDF through water soluble fertilizer, and F5- $60 \%$ of RDF through water soluble fertilizer and sub plot treatment included three fertigation intervals (S) viz., $S_{1^{-}}$at 4 days interval, $S_{2}$ at 8 days interval and $S_{3^{-}}$at 12 days interval. The results revealed superiority of fertigation treatment $\mathrm{F}_{2}(120 \%$ of RDF through water soluble fertilizer) for vine length $(426.70,385.00$ and $405.85 \mathrm{~cm}$ respectively), number of branches $(20.60,26.40$ and 23.50 respectively) both at 90 DAS and leaf area $\left(73.20,74.46\right.$ and $68.03 \mathrm{~cm}^{2}$ respectively) whereas, treatment $\mathrm{S}_{1}$ (fertigation at 4 days interval) which showed maximum values in both the season and pooled mean for above characters like vine length $(408.58,368.68$ and $388.63 \mathrm{~cm}$ respectively), number of branches (19.48, 25.24 and 22.36 respectively) both at 90 DAS and leaf area $\left(69.80,70.20\right.$ and $65.59 \mathrm{~cm}^{2}$ respectively). As regards the treatment combination that the application of $120 \%$ of RDF through water soluble fertilizer (ferigation) with 4 days interval recorded highest vine length at 90 DAS $(460.60,429.00$ and $444.80 \mathrm{~cm}$ respectively), number of branches at $90 \mathrm{DAS}(24.70,28.60$ and 26.65 respectively) and leaf area during kharif season, summer season and pooled mean.
\end{abstract}

Keywords: Bitter gourd, fertigation, growth, vine length

\section{Introduction}

Bitter gourd (Momordica charantia L.) is one of the most important cucurbitaceous vegetable of grown in Maharashtra state for its immature tuberculate fruits which have unique bitter taste. The area and production of bitter gourd in India is around 97 thousand hectors and 1137 thousand metric tons respectively (Anon, 2018) ${ }^{[1]}$. Its tender fruits are cooked or pickled. The fruit accumulates bitterness due to build up of three pentacyclic triterpenes momordicin, momordicinin and momordicilin. Fruits are rich source of vitamin C, iron, calcium, phosphorous, protein and carbohydrates. Fruits have medicinal value and are used for curing diabetes, asthma and rheumatism. It is used as a hypoglycemic and anti diabetic agent because it Posses hypoglycemic (blood sugar lowering) properties. It has analgesic, immune suppressive and anti-tumor properties useful in killing bacteria, viruses, fights free radicals, cancer cells, leukemia cells, prevents tumors, cleanses blood, reduce inflammation, reduces blood sugar and balance hormones. (Triveni et al., 2015) ${ }^{[11]}$. Enhancement of yield and quality of bittergourd is always proved to be important task which can be met out through advance technique like fertigation. Fertigation plays a major role for nutrient application to increase the nutrient use efficiency. Fertigation has the potential to supply a right mixture of water and nutrients to the root zone and thus meeting plants water and nutrient requirements in most efficient possible manner during a growing season. With fertigation, nutrient use efficiency is increased and the loss of nutrients to the ground water is reduced. Hence a precise scheduling of irrigation and fertilizer applications has provided sustainable production solution of every crop (Thenmozhi et al., 2017) ${ }^{[3]}$. Split fertilizer applications help to avoid salt damages to the crop and improves germination rate. Applying smaller amounts of fertilizers at shorter intervals reduce salt stress. Split fertilizer applications can play an important role in a nutrient management strategy that is productive, profitable and environmentally responsible.
Correspon Nagre

Dean, Department of Vegetable Science, Faculty of Horticulture, Dr. P.D.K.V., Akola Maharashtra, India 
Split application can be an important part of a successful nutrient management program and can help growers achieve right source, right rate, right time and right place. Dividing total nutrient application into more and smaller quantity can help growers to enhance nutrient efficiency, promote optimum yields and mitigate the loss of nutrients.

\section{Material and Methods}

A field experiment with bitter gourd veriety 'Phule green gold' was conducted during kharif 2018-2019 and summer 2019-2020 at the Chilli and Vegetable Research Unit, Dr. Panjabrao Deshmukh Krishi Vidyapeeth, Akola. The experiment was conducted in Split Plot Design with two replications. The main plot treatment including five fertigation levels $(F)$ viz., $F_{1}-100 \%$ of RDF (100:50:50kg/ha NPK) through soil as a straight fertilizer, $F_{2}-120 \%$ of RDF (120:60:60kg/ha NPK) through water soluble fertilizer, $F_{3}$ $100 \%$ of $\mathrm{RDF}(100: 50: 50 \mathrm{~kg} / \mathrm{ha}$ NPK) through water soluble fertilizer, $\mathrm{F}_{4}-80 \%$ of $\mathrm{RDF}(80: 40: 40 \mathrm{~kg} / \mathrm{ha} \mathrm{NPK})$ through water soluble fertilizer, and $\mathrm{F}_{5}-60 \%$ of RDF $(60: 30: 30 \mathrm{~kg} / \mathrm{ha}$ NPK) through water soluble fertilizer and sub plot treatment included three Fertigation intervals (S) viz., $\mathrm{S}_{1^{-}}$at 4 days interval, $S_{2}$ at 8 days interval and $S_{3}$ at 12 days interval. The RDF (100:50:50 kg/ha NPK) through soil as a straight fertilizer used urea, muriate of potash and single super phosphate, where as water soluble fertilizer viz., urea and 19:19:19 were used to provide the major nutrient requirement for the crop through fertigation. Seeds were sown uniformly at a spacing of $2 \times 1 \mathrm{~m}$. After sowing, the crop was irrigated at four days interval in kharif and daily in summer for about 2 hours with drip system. Bower system established with plastic net and vines were trailed on this. Online dripper (1 dripper plant ${ }^{-1}$ ) with discharge rate of $4 \mathrm{~L} \mathrm{hr}^{-1}$ were used. The data relating to growth attributes were statistically analysed by applying the technique of analysis of variance (ANOVA) for split plot design and the significance was tested by $\mathrm{F}$ test (Snedecor and Cohran, 1975) ${ }^{[10]}$. In cases where $F$ values were found significant, critical differences (CD) were calculated.

\section{Result and Discussion \\ Fertigation levels}

The growth parameters of bittergourd were significantly influenced by different fertigation levels. The data presented in table 1 and 2 revealed that the maximum vine length was recorded by $\mathrm{F}_{2}$ i.e. $120 \%$ RDF through fertigation in both season and pooled mean $(426.70,385$ and $405.85 \mathrm{~cm}$ respectively in 90 DAS) however, it was at par with $\mathrm{F}_{3}(100 \%$ RDF through fertigation) at 60 and 90 DAS during both season and pooled mean, and $\mathrm{F}_{4}$ at 90 DAS during summer season. NPK fertigation at higher doses significantly increased the length of vines (Abraham et al., 2018) ${ }^{[4]}$. The maximum and vigorous plant growth was due to frequent and increased application of fertilizers applied directly in vicinity of root zoon increases the availability and uptake of nutrient which leads to increase the cell size and cell elongation. The results were supported reported by Lee et al., (2005) ${ }^{[5]}$, Sharma et al. (2009) ${ }^{[6]}$ and Jilani et al. (2009). The treatment F2 i.e. $120 \%$ RDF through fertigation also produced more number of branches during both the season and pooled mean (13.23 and 20.60 respectively during kharif season), (17.87 and 26.40 respectively during summer season) and (15.55 and 23.50 respectively in pooled mean) which was at par with $F_{1}$ during summer season at 60 and 90 DAS (13.00 and 20.60 respectively). The variation in number of branches per vine may be due to varied nutrient supply levels. The role of nitrogen is important as an essential constituent of chlorophyll, which has got a direct bearing on the rate of photosynthesis and as a constituent of protein for the promotion of growth of meristematic tissues. The effect of nitrogen in promoting vegetative growth and also the role of potassium as an essential element for promotion of growth of meristematic tissue has been well established (Tisdale et al., 1985). For both the season, fertigation levels had significant influence over leaf area. In kharif and summer season the maximum leaf area was recorded by $F_{2}\left(73.20\right.$ and $74.46 \mathrm{~cm}^{2}$ respectively), however, it was at par with treatment $F_{3}$ in both the season as well as $\mathrm{F}_{4}$ during summer season. The effect of nitrogen in enhancing the leaf area is well established phenomena and increased levels of nutrition usually had positive relationship with growth (Sarro et al., 1989) ${ }^{[7]}$. There was non significant influence of different fertigation levels on chlorophyll content of leaf during both the season and pooled mean. However numerically maximum chlorophyll content was reported by $F_{2}(35.29,43.76$ and $39.52 \mathrm{mg} / \mathrm{g}$ respectively) during both the season and pooled mean.

\section{Fertigation intervals}

The data presented in table 1 and 2 further revealed that during both season and pooled mean, the treatment $S_{1}$ i.e. fertigation at 4 days interval recorded significantly maximum vine length $(408.58,368.68$ and $388.63 \mathrm{~cm}$ respectively in 90 DAS). The frequent application of recommended dose of N, P and $\mathrm{K}$ at 4 days interval increases the availability of these nutrients leading to increased uptake of $\mathrm{N}, \mathrm{P}$ and $\mathrm{K}$ during growth period which increases protein and protoplasm synthesis for higher rate of mitosis resulting in increased growth attributes. These results are in agreement with those reported by Hari et al., (2016) ${ }^{[2]}$, Al-Jaloud et al. (1999) ${ }^{[8]}$ and Shinde et al. (2010) ${ }^{[9]}$. Fertigation at 4 days interval also produced maximum number of branches during both season and pooled mean (12.24 and 19.48 respectively during kharif season), (17.48 and 25.24 respectively during summer season) and (14.86 and 2.36 at pooled mean) at 60 and 90 DAS. Treatment $S_{1}$ i.e. 4 days interval also recorded maximum leaf area (69.80, 70.20 and $70.00 \mathrm{~cm}^{2}$ respectively), however, it was at par with $\mathrm{S}_{2}$ i.e. fertigation at 8 days interval during pooled mean $\left(63.88 \mathrm{~cm}^{2}\right)$. As regards, the chlorophyll content, fertigation intervals did not show any significant influence during kharif season, however, during summer season and pooled mean it was significant. The treatment $S_{2}$ recorded numerically maximum chlorophyll content of leaf $33.68 \mathrm{mg} / \mathrm{g}$ during kharif season. Whereas, $\mathrm{S}_{1}$ recorded numerically maximum chlorophyll content of leaf $(41.82$ and $37.56 \mathrm{mg} / \mathrm{g}$ respectively) during summer season and pooled mean.

\section{Interaction effect}

Considering the interaction effects of fertigation levels and intervals on growth performance of bittergourd at 60 and 90 DAS, the treatment $\mathrm{F}_{2} \mathrm{~S}_{1}$ i.e. $120 \%$ RDF through fertigation with 4 days interval recorded significantly maximum vine length (310.02 and $460.60 \mathrm{~cm}$ respectively for kharif season), (429.00 cm respectively for summer season at 90 DAS) and (308.76 and $444.80 \mathrm{~cm}$ respectively for pooled mean) during both season and pooled mean. Treatment $\mathrm{F}_{2} \mathrm{~S}_{1}$ at 60 and 90 DAS (15.60 and 24.70 respectively for kharif season), (20.70 and $28.60 \mathrm{~cm}$ respectively for summer season) and (18.15 and 26.65 respectively for pooled mean) which was at par with $\mathrm{F}_{3} \mathrm{~S}_{1}$ (120\% RDF through fertigation with 4 days interval) during kharif season at 60 DAS and during summer season at 
90 DAS (14.50 and 28.00 respectively). The maximum leaf area was also recorded by treatment $\mathrm{F}_{2} \mathrm{~S}_{1}$ i.e. $120 \% \mathrm{RDF}$ through fertigation with 4 days interval $\left(78.66\right.$ and $79.09 \mathrm{~cm}^{2}$ respectively) during both the season which was at par with $\mathrm{F}_{3} \mathrm{~S}_{1}$ i.e. $100 \% \mathrm{RDF}$ through fertigation with 4 days interval
(76.47 and $76.93 \mathrm{~cm}^{2}$ respectively) during both the season. The interaction effect between fertigation levels and intervals on leaf area and chlorophyll content of leaf was found to be non significant during both the season and pooled mean.

Table 1: Effect of fertigation levels and intervals on Vine length $(\mathrm{cm})$ at 60 and 90 DAS and Leaf area $\left(\mathrm{cm}^{2}\right)$

\begin{tabular}{|c|c|c|c|c|c|c|c|c|c|}
\hline \multirow{3}{*}{ Treatments } & \multicolumn{6}{|c|}{ Vine length $(\mathrm{cm})$} & \multirow{2}{*}{\multicolumn{3}{|c|}{ Leaf area $\left(\mathrm{cm}^{2}\right)$}} \\
\hline & \multicolumn{3}{|c|}{ 60 DAS } & \multicolumn{3}{|c|}{90 DAS } & & & \\
\hline & Kharif & Summer & Pooled & Kharif & Summer & Pooled & Kharif & Summer & Pooled \\
\hline \multicolumn{10}{|c|}{ Ferigation Levels (F) } \\
\hline $\mathrm{F}_{1}$ & 235.20 & 207.00 & 221.10 & 364.47 & 289.67 & 327.07 & 61.50 & 55.37 & 57.00 \\
\hline $\mathrm{F}_{2}$ & 285.37 & 277.47 & 281.42 & 426.70 & 385.00 & 405.85 & 73.20 & 74.46 & 68.03 \\
\hline $\mathrm{F}_{3}$ & 274.46 & 262.93 & 268.70 & 414.20 & 372.83 & 393.52 & 71.82 & 72.53 & 66.91 \\
\hline $\mathrm{F}_{4}$ & 262.87 & 255.03 & 258.95 & 400.43 & 360.67 & 380.55 & 70.45 & 70.80 & 66.03 \\
\hline $\mathrm{F}_{5}$ & 218.20 & 217.23 & 217.72 & 338.20 & 309.77 & 323.98 & 54.46 & 62.59 & 59.37 \\
\hline F test & Sig. & Sig. & Sig. & Sig. & Sig. & Sig & Sig. & Sig. & NS \\
\hline $\mathrm{SE}(\mathrm{m}) \pm$ & 2.09 & 5.56 & 2.51 & 4.18 & 8.46 & 3.04 & 1.28 & 0.58 & 1.98 \\
\hline CD 5\% & 8.41 & 22.43 & 10.13 & 16.86 & 34.11 & 12.26 & 5.01 & 2.29 & - \\
\hline \multicolumn{10}{|c|}{ Fertigation Intervals (S) } \\
\hline $\mathrm{S}_{1}$ & 271.54 & 262.62 & 267.08 & 408.58 & 368.68 & 388.63 & 69.80 & 70.20 & 65.59 \\
\hline $\mathrm{S}_{2}$ & 251.92 & 244.30 & 248.11 & 388.12 & 343.62 & 365.87 & 66.93 & 67.47 & 63.88 \\
\hline $\mathrm{S}_{3}$ & 242.20 & 224.88 & 233.54 & 369.7 & 318.46 & 344.08 & 62.13 & 63.79 & 60.94 \\
\hline $\mathrm{F}$ test & Sig. & Sig. & Sig. & Sig. & Sig. & Sig & Sig. & Sig. & Sig. \\
\hline $\mathrm{SE}(\mathrm{m}) \pm$ & 1.40 & 4.45 & 1.80 & 1.57 & 2.13 & 1.61 & 0.44 & 0.21 & 0.56 \\
\hline CD 5\% & 4.49 & 14.21 & 5.76 & 5.02 & 6.81 & 5.14 & 1.40 & 0.67 & 1.76 \\
\hline \multicolumn{10}{|c|}{ Interaction effects (F X S) } \\
\hline $\mathrm{F}_{1} \mathrm{~S}_{1}$ & 236.60 & 207.50 & 222.05 & 363.30 & 293.40 & 328.35 & 61.47 & 55.83 & 58.65 \\
\hline $\mathrm{F}_{1} \mathrm{~S}_{2}$ & 233.00 & 204.50 & 218.75 & 364.00 & 287.70 & 325.85 & 61.51 & 55.20 & 58.36 \\
\hline $\mathrm{F}_{1} \mathrm{~S}_{3}$ & 236.00 & 209.00 & 222.50 & 366.10 & 287.90 & 327.00 & 61.52 & 55.08 & 58.30 \\
\hline $\mathrm{F}_{2} \mathrm{~S}_{1}$ & 310.02 & 307.50 & 308.76 & 460.60 & 429.00 & 444.80 & 78.66 & 79.09 & 78.88 \\
\hline $\mathrm{F}_{2} \mathrm{~S}_{2}$ & 280.10 & 277.40 & 278.75 & 422.40 & 382.50 & 402.45 & 73.79 & 74.08 & 73.94 \\
\hline $\mathrm{F}_{2} \mathrm{~S}_{3}$ & 266.00 & 247.50 & 256.75 & 397.10 & 343.50 & 370.30 & 67.15 & 70.22 & 68.69 \\
\hline $\mathrm{F}_{3} \mathrm{~S}_{1}$ & 293.37 & 291.50 & 292.44 & 438.90 & 404.00 & 421.45 & 76.47 & 76.93 & 76.70 \\
\hline $\mathrm{F}_{3} \mathrm{~S}_{2}$ & 270.60 & 264.20 & 267.40 & 412.80 & 378.50 & 395.65 & 73.16 & 73.30 & 73.23 \\
\hline $\mathrm{F}_{3} \mathrm{~S}_{3}$ & 259.40 & 233.10 & 246.25 & 390.90 & 336.00 & 363.45 & 65.84 & 67.37 & 66.61 \\
\hline $\mathrm{F}_{4} \mathrm{~S}_{1}$ & 287.40 & 283.00 & 285.20 & 425.30 & 396.00 & 410.65 & 75.06 & 75.25 & 75.16 \\
\hline $\mathrm{F}_{4} \mathrm{~S}_{2}$ & 260.60 & 255.60 & 258.10 & 398.30 & 358.00 & 378.15 & 72.52 & 72.12 & 72.32 \\
\hline $\mathrm{F}_{4} \mathrm{~S}_{3}$ & 240.60 & 226.50 & 233.55 & 377.70 & 328.00 & 352.85 & 63.77 & 65.04 & 64.41 \\
\hline $\mathrm{F}_{5} \mathrm{~S}_{1}$ & 230.30 & 223.60 & 226.95 & 354.80 & 321.00 & 337.90 & 57.33 & 63.89 & 60.61 \\
\hline $\mathrm{F}_{5} \mathrm{~S}_{2}$ & 215.30 & 219.80 & 217.55 & 343.10 & 311.40 & 327.25 & 53.67 & 62.64 & 58.16 \\
\hline $\mathrm{F}_{5} \mathrm{~S}_{3}$ & 209.0 & 208.30 & 208.65 & 316.70 & 296.90 & 306.80 & 52.38 & 61.24 & 56.81 \\
\hline $\mathrm{F}$ test & Sig. & NS & Sig. & Sig. & Sig. & Sig. & Sig. & Sig. & NS \\
\hline $\mathrm{SE}(\mathrm{m}) \pm$ & 3.15 & 0.10 & 4.04 & 3.51 & 4.80 & 3.60 & 0.99 & 0.48 & 1.25 \\
\hline CD 5\% & 9.93 & -- & 12.73 & 11.06 & 15.0 & 11.30 & 3.12 & 1.50 & - \\
\hline
\end{tabular}

Table 2: Effect of fertigation levels and intervals on number of branches (at 60 and 90 DAS) and Chlorophyll content of leaf

\begin{tabular}{|c|c|c|c|c|c|c|c|c|c|}
\hline \multirow{3}{*}{ Treatments } & \multicolumn{6}{|c|}{ Number of branches } & \multirow{2}{*}{\multicolumn{3}{|c|}{$\begin{array}{l}\text { Chlorophyll content of leaf } \\
(\mathrm{mg} / \mathrm{g})\end{array}$}} \\
\hline & \multicolumn{3}{|c|}{60 DAS } & \multicolumn{3}{|c|}{90 DAS } & & & \\
\hline & Kharif & Summer & Pooled & Kharif & Summer & Pooled & Kharif & Summer & Pooled \\
\hline \multicolumn{10}{|c|}{ Ferigation Levels (F) } \\
\hline $\mathrm{F}_{1}$ & 9.27 & 13.00 & 11.13 & 14.30 & 20.60 & 17.45 & 31.48 & 38.84 & 35.16 \\
\hline $\mathrm{F}_{2}$ & 13.23 & 17.87 & 15.55 & 20.60 & 26.40 & 23.50 & 35.29 & 43.76 & 39.52 \\
\hline $\mathrm{F}_{3}$ & 12.43 & 17.30 & 14.87 & 19.20 & 25.77 & 22.48 & 33.44 & 41.38 & 37.41 \\
\hline $\mathrm{F}_{4}$ & 11.87 & 16.80 & 14.33 & 18.20 & 25.10 & 21.65 & 33.96 & 39.12 & 36.54 \\
\hline $\mathrm{F}_{5}$ & 7.50 & 14.10 & 10.80 & 13.03 & 21.50 & 17.27 & 33.24 & 39.84 & 36.54 \\
\hline F test & Sig. & Sig. & Sig. & Sig. & Sig. & Sig. & NS & NS & NS \\
\hline $\mathrm{SE}(\mathrm{m}) \pm$ & 0.12 & 0.21 & 0.11 & 0.45 & 0.16 & 0.21 & 0.054 & 0.07 & 0.06 \\
\hline CD 5\% & 0.49 & 0.82 & 0.43 & 1.78 & 0.63 & 0.81 & - & - & - \\
\hline \multicolumn{10}{|c|}{ Fertigation Intervals (S) } \\
\hline $\mathrm{S}_{1}$ & 12.24 & 17.48 & 14.86 & 19.48 & 25.24 & 22.36 & 33.30 & 41.82 & 37.56 \\
\hline $\mathrm{S}_{2}$ & 10.64 & 15.40 & 13.02 & 16.92 & 23.90 & 20.41 & 33.68 & 41.38 & 37.53 \\
\hline $\mathrm{S}_{3}$ & 9.70 & 14.56 & 12.13 & 14.80 & 22.48 & 18.64 & 33.46 & 38.56 & 36.01 \\
\hline $\mathrm{F}$ test & Sig. & Sig. & Sig. & Sig. & Sig. & Sig. & NS & Sig. & Sig. \\
\hline $\mathrm{SE}(\mathrm{m}) \pm$ & 0.17 & 0.11 & 0.07 & 0.18 & 0.14 & 0.11 & 0.04 & 0.06 & 0.04 \\
\hline CD 5\% & 0.52 & 0.36 & 0.21 & 0.55 & 0.43 & 0.35 & - & 0.19 & 0.12 \\
\hline \multicolumn{4}{|c|}{ Interaction effects (F X S) } & & & & & & \\
\hline $\mathrm{F}_{1} \mathrm{~S}_{1}$ & 9.20 & 13.10 & 11.15 & 14.00 & 20.30 & 17.15 & 30.95 & 37.72 & 34.34 \\
\hline
\end{tabular}




\begin{tabular}{|c|c|c|c|c|c|c|c|c|c|}
\hline $\mathrm{F}_{1} \mathrm{~S}_{2}$ & 9.20 & 13.00 & 11.10 & 14.60 & 20.70 & 17.65 & 33.31 & 40.80 & 37.06 \\
\hline $\mathrm{F}_{1} \mathrm{~S}_{3}$ & 9.40 & 12.90 & 11.15 & 14.30 & 20.80 & 17.55 & 30.18 & 37.99 & 34.09 \\
\hline $\mathrm{F}_{2} \mathrm{~S}_{1}$ & 15.60 & 20.70 & 18.15 & 24.70 & 28.60 & 26.65 & 34.89 & 46.74 & 40.82 \\
\hline $\mathrm{F}_{2} \mathrm{~S}_{2}$ & 12.80 & 17.10 & 14.95 & 20.30 & 26.40 & 23.35 & 35.35 & 44.63 & 39.99 \\
\hline $\mathrm{F}_{2} \mathrm{~S}_{3}$ & 11.30 & 15.80 & 13.55 & 16.80 & 24.20 & 20.50 & 35.63 & 39.90 & 37.77 \\
\hline $\mathrm{F}_{3} \mathrm{~S}_{1}$ & 14.50 & 19.80 & 17.15 & 22.80 & 28.00 & 25.40 & 33.19 & 43.70 & 38.45 \\
\hline $\mathrm{F}_{3} \mathrm{~S}_{2}$ & 12.00 & 16.60 & 14.30 & 18.80 & 25.70 & 22.25 & 32.65 & 40.84 & 36.75 \\
\hline $\mathrm{F}_{3} \mathrm{~S}_{3}$ & 10.80 & 15.50 & 13.15 & 16.00 & 23.60 & 19.80 & 34.48 & 39.60 & 37.04 \\
\hline $\mathrm{F}_{4} \mathrm{~S}_{1}$ & 13.80 & 19.20 & 16.50 & 22.00 & 27.20 & 24.60 & 33.92 & 40.30 & 37.11 \\
\hline $\mathrm{F}_{4} \mathrm{~S}_{2}$ & 11.70 & 16.10 & 13.90 & 17.70 & 25.20 & 21.45 & 34.15 & 40.54 & 37.35 \\
\hline $\mathrm{F}_{4} \mathrm{~S}_{3}$ & 10.10 & 15.10 & 12.60 & 14.90 & 22.90 & 18.90 & 33.81 & 36.52 & 35.17 \\
\hline $\mathrm{F}_{5} \mathrm{~S}_{1}$ & 8.10 & 14.60 & 11.35 & 13.90 & 22.10 & 18.00 & 33.55 & 40.62 & 37.09 \\
\hline $\mathrm{F}_{5} \mathrm{~S}_{2}$ & 7.50 & 14.20 & 10.85 & 13.20 & 21.50 & 17.35 & 32.95 & 40.10 & 36.53 \\
\hline $\mathrm{F}_{5} \mathrm{~S}_{3}$ & 6.90 & 13.50 & 10.20 & 12.00 & 20.90 & 16.45 & 33.22 & 38.79 & 36.01 \\
\hline $\mathrm{F}$ test & Sig. & Sig. & Sig. & Sig. & Sig. & Sig. & $\mathrm{NS}$ & $\mathrm{NS}$ & $\mathrm{NS}$ \\
\hline $\mathrm{SE}(\mathrm{m}) \pm$ & 0.37 & 0.25 & 0.15 & 0.39 & 0.30 & 0.25 & 0.08 & 0.13 & 0.09 \\
\hline $\mathrm{CD} 5 \%$ & 1.17 & 0.79 & 0.47 & 1.24 & 0.96 & 0.78 & - & - & - \\
\hline
\end{tabular}

\section{Conclusion}

It can be summed up that maximum growth performance viz., vine length, number of branches and leaf area etc. of bittergourd in desirable direction could be achieved by application of 120\% RDF (120:60:60 kg/ha NPK) through fertigation with 4 days interval in equal splits which ultimately resulted in improving yield of bittergourd.

\section{References}

1. Anonymous. Horticultural Statistics at a Glance 2018.

2. Hari AA, Girija Devi L. Studies on fertigation in bitter gourd (Momordica charantia L.) Journal of Crop and Weed 2016;12(2):91-95.

3. Thenmozhi M, Kottiswaran SV. Effect of fertigation scheduling under drip irrigation with different black polyethylene mulching in Capsicum crop under polyhouse and open field conditions. Journal of Pharmacognosy and Phytochemistry 2017;6(5):24852490.

4. Abraham Rincy K, Munsi Partha Sarathi, Dulal Chandra Manna. Effect of drip irrigation, fertigation and mulching on growth and dry matter accumulation in bitter gourd. J Krishi Vigyan 2018;6(2):61-67.

5. Lee JH, Park SK, Lee YH, Lee YB. Effect of fertigation level and frequency on uptake of nutrients, growth and yield in cucumber. J Korean Soci. Horti. Sci 2005;46(6):356-362.

6. Sharma MK, Negi S, Kumari S. Effect of different growing media and fertigation levels on production of cucumber (Cucumis sativus L.) under protected conditions in the hills. Indian J Agric. Sci 2009;79(11):853-856.

7. Sarro MJ, Sanchez MJ, Miyar C, Zoronoza R. Nutritional requirements of two rose cultivars grown in gravel culture. Acta Hort 1989;246:219-222.

8. Al-Jaloud A, Ongkingco T, Al-Saharay S, Al-Bashir W. Effect of fertigation requencies on growth and yield of greenhouse cucumber. Saaudi. J Bio. Sci 1999;(6)2:156166.

9. Shinde JB, Malunjkar BD, Raut RS, Patil PD, Thawal DW. Response of cucumber to fertigation under drip irrigation system. Bioinfolet 2010;7(2):161-164.

10. Snedecor GW, Cohran WG. Statistical Methods. Oxford and IBH Publishing Company, New Delhi 1975, 593.

11. Triveni V, Mishra H, Pattanayak S, Sahoo G, Thomson T. Effect of inorganic, organic fertilizers and biofertilizers on growth, flowering, yield and quality attributes of Bitter guards (Momordica Charantia L), International journal of farm science 2015;5(1):24-29. 